\title{
The effect of organizational commitment, competence on Job satisfaction and employees performance in Maluku Governor's Office
}

\author{
Bernard C. Renyut ${ }^{1)}$,H. Basri Modding ${ }^{2)}$, Jobhar Bima ${ }^{3)}$, St. Sukmawati ${ }^{4)}$ \\ ${ }^{1)}$ (Doctoral Student in the Faculty of Economics, University of Muslim Indonesia \\ ${ }^{2,3,4)}$ (Faculty of Economics, University of Muslim Indonesia)
}

\begin{abstract}
This study explores some of causality between variables include; the influence of organizational commitment and competence to job satisfaction as the first causality then the influence of organizational commitment, competence to employee performance as the second and final causality influence job satisfaction on employee performance, as well as to analyze the effect of organizational commitment, job satisfaction and competence on employee's performance. The research was conducted at the Maluku Governor's Office, involving 632 employees as a population then set at 244 as respondents. The WarpPLS results found that organizational commitment positive and significant impact on job satisfaction, on the other part, organizational commitment has a positive effect and insignificant effect on employee performance, organizational commitment directly positive and significant effect on employee performance, job satisfaction is a positive and significant effect on employee performance, the organizational commitment as indirect effect is positive not significant on employee performance as a mediated job satisfaction and employee competence indirectly is a positive and significant effect on employee performance as a mediated job satisfaction
\end{abstract}

Keywords: Organizational commitment, competence, job satisfaction. Employee performance

Date of Submission: 03-10-2017

Date of acceptance: 16-11-2017

\section{Introduction}

The era of regional autonomy demanded the development of human resources needs and strategic step for any local government. Substance important human resource development in the era of regional autonomy and good governance is a paradigm shift, attitudes, values and performance of the government apparatus. Strategic role of the government will be largely supported by a bureaucracy capable of carrying out its duties and functions. One of the major challenges facing the bureaucracy is to implement an effective and efficient performance because all this bureaucracy is identified with the performance convoluted. Employee performance bureaucracy needs to be reformed in order to respond to the increasingly rapid changes that are expected to create a performance of the apparatus that is able to work professionally. Government agencies as a non-profit organization always fix themselves to improving human resources through increased organizational commitment, and competence towards achieving job satisfaction and employee performance in carrying out the duties and functions. Human Resources organizations always pay attention to job satisfaction and improved performance of everyone in the organization. Job satisfaction is a personal value that determines the achievement of the performance. And the performance itself is an important assessment for each employee Maluku provincial governor's office to pay attention to job satisfaction and employee performance according to standards of civil servants (Wirawan, 2014: 13).

Assessment of the performance of employees to be important to be noticed and considered by an employee in the Maluku Governor's Office is now seen in realization of employee performance through improvements in the quantity, quality, efficiency and effectiveness of employees in performing basic tasks and functions optimally.

Table 1. Employee's performance at the office of Maluku Governor's Office

\begin{tabular}{|c|c|c|}
\hline \multirow{2}{*}{ Years } & \multicolumn{2}{|c|}{ Employee Performance (\%) } \\
\cline { 2 - 3 } & Actual & Target \\
\hline $\mathbf{2 0 1 4}$ & $\mathbf{8 7 , 5}$ & $>90$ \\
\hline $\mathbf{2 0 1 5}$ & $\mathbf{8 5 , 2}$ & $>90$ \\
\hline $\mathbf{2 0 1 6}$ & $\mathbf{8 5 , 2}$ & $>90$ \\
\hline
\end{tabular}

Determining of target $>90 \%$ determined by the value of the achievement of Goal employee performance (SKP) stated criteria of $>90$ to reach the target and $<90$ otherwise not reached the target. The percentage 
decrease in performance-based employee performance and duties and functions of employees achieved in 2014 realized $87.5 \%$, while in 2016 decreased by $85.2 \%$ and did not reach the target of $<90 \%$. The conditions in the causes for their employees to tasks perform that differentiate the work according to their own wishes. While demanding organizations to assign tasks and responsibilities are optimal. In addition, the implementation of the tasks performed by employees often complain about the SKPD because in completing the work less according to plan daily work, the work is given less according to the standard, the error rate is often the case in the outcome of a given job, the duties and responsibilities of the job provided always late in settling, presence is always late and return home earlier than the specified time, a lot of free time is used for relaxing. These facts should be considered to improve and improve employee performance through the application of the theory of employee performance (Schemerhorn, 2007: 66) that the success of an organization in achieving its objectives judged by the performance of employees or the results achieved. Understanding the performance of employees would not be separated from the measured performance assessment. Reference to measure employee performance seen from the achievement of the work reported annually by the head unit SKPD to the Maluku Governor's Office

Employee performance decline is not independent of the contribution of perceived job satisfaction in performing their duties and functions. A growing reality in Maluku Governor's Office shows that hard improving employee performance if not supported with the job satisfaction. Achievement of the employee's performance is realized by first realizing job satisfaction (Rival and Sedarmayanti, 2008: 96). The decline in the performance of employees as noted indicates that an employee works is not optimal in performing their duties and functions. Indications that the cause of the employee's performance has decreased due to the level of employee satisfaction is not met, especially in carrying out the work itself, the work presented is not to completion, the work does not have a target completion, the list of schedules in the achievement in completing the job, benefits and bonuses given less accordingly, or in other words the employee expectations cannot be realized by the leadership. The reality on the ground shows that the apparent persistence of the employees who are being lazy in carrying out the work given to employees as an indication that employees are less concerned with the work itself that cause employees to feel less in line with the work areas occupied, employees are less appreciated what he was doing, do not dare to accept the challenge of working given by the leadership, there is no concern of the leadership or not appreciated from the work achieved and the lack of incentives for employees in completing a given job.

The above conditions indicate that the level of employee satisfaction were low that it causes a decrease in performance of staff in doing basic tasks and functions, for it takes a more serious approach in reducing these conditions, such as by applying the theory of two factors that job satisfaction can improve employee performance (Herzberg; cited in Keban, 2007: 46) that the job satisfaction of the disclosure a person look unpleasant or disappointing feeling for the work performed. Job satisfaction needs to be given to employees in order to realize the pleasure of working that is expected to improve its performance. Empirical evidence suggests that there is a gap Research in analyzing the effect of organizational commitment on job satisfaction and employee performance (Charles M.Coco 2011; Hotman, 2011; Soleiman Yahyazadeh et al., 2012; Ida Respatiningsih and Frans sudirjo, 2015). The effect of competencies, organizational commitment on employee performance (Anik Suwarni, 2008; Julian Yoseph, 2012; Hotman, 2011; Danang M. Wibowo et al. 2014).

\section{Literature review and hypothesis Development}

\section{Organizational Commitment}

When the organization offers employment and job applicants accept the offer, the job applicant has been part of the organization. There are many reasons why an organization should try to improve their employees' organizational commitment. For example, many studies have found that more and more employees are committed to the organization; the employee will try to do better in completing tasks. In addition, employees who are committed also will increase the productivity of employees because the employees feel at one with the organization and work to achieve organizational goals. With the flavors blend with the employee, the employee did not think to leave the organization so that said high organizational commitment would reduce the desire to move employees (Richard M. Steers and Lyman W. Porter, 1991: 290). Commitment as a condition in which is an impartial organization and goals and desires to retain membership in the organization (Robbins and Judge, 2007; 111). The views of other experts define organizational commitment as the degree to which employees believe and accept the organization's goals and will stay or not will leave it (Mathis and Jackson, cited in Sopiah, 155).

The dimensions of organizational commitment are most often used by researchers are the dimensions of organizational commitment that developed Meyer, Allen and Smith; cited in Jerald Greenberg and Robert A. Baron (2008), namely: (1) the affective commitment refers to the emotional connection to the organization's members. People want to continue to work for these organizations because they agree with the goals and values in the organization. People with levels of affective commitment are high have a desire to remain in the 
organization because they support the goals of the organization and is willing to help to achieve these objectives, (2) continuance commitment refers to the desire of employees to remain in the organization for their calculation or analysis of profit and loss in which the perceived economic value of survive in an organization than by leaving the organization. The longer employees stay with their organization, the more they are afraid of losing what they have given to the organization during this time, (3) normative commitment refers to the feelings of employees where they are required to remain in the organization because of pressure from others, Employees who have a high level of normative commitment will be very attentive to what other people say about them if they leave the organization. They do not want to disappoint their boss and co-workers worried if they think badly of them because of the resignation.

Empirical evidence suggests that organizational commitment negative and significant effect on job satisfaction (Anik Suwarni, 2008). Organizational commitment is negative and insignificant effect on job satisfaction (Danang Mukti Wibowo, 2014). The findings differ from the findings of other researchers that organizational commitment is positive and significant effect on job satisfaction (Hotman, 2011; Charles M. Coco, 2011; Hidayat Pontoh, 2012; Soleiman Yahyazadeh et al., 2012). In other contextual, organizational commitment has insignificant effect on employee performance (Danang Mukti Wibowo, 2014; Deddy Pandaleke, 2016). The findings are disputed by other researchers that organizational commitment is a negative and significant effect on employee performance (Anik Suwarni, 2008). Organizational commitment positive and significant effect on employee performance (Diana Sulianti Tobing, 2009; Hotman, 2011; Charles M. Coco, 2011; Hidayat Pontoh, 2012; Soleiman Yahyazadeh et al., 2012; Ida Respatiningsih and Frans Sudirjo, 2015; Ni Komang Sri Wahyudi and I Gede Adnyana Sudibya, 2016).

$\mathrm{H}_{1}$ : Organizational Commitment positive and significant effect on job satisfaction

$\mathrm{H}_{2}$ : Organizational Commitment positive and significant effect on employee performance

\section{Competence}

Competence is an ability to execute or perform a job or task that is based on skills and knowledge and is supported by the work attitude demanded by the job them. Competence as a person's ability to produce at a satisfactory level in the workplace, also show the characteristics of the knowledge and skills possessed or needed by any individual which enables them to perform their duties and responsibilities effectively and improve the quality standards Professional employment (David Mc. Clelland, 1997: 93). There are two terms that arise from two different streams of the concept of conformity in the job. That term is competence is a description of the behavior, and skills which is a description of the task or the work. (Palan, 2007: 5) Although the difference in the meanings of both terms is widely accepted, but its use is still often used interchangeably, which causes everyone has a different understanding. Most people use the term competence and the like to create understanding themselves according to their interests. The views of other experts, as proposed by Zamkee (1982) Cited in Palan (2007: 6) say that competence can mean a variety of follow meaning.

The competence of human resources is based on the theory proposed by Donald (2007: 86) explains that access to self-development is basically the recognition of the competence of human resources by introducing the concept of "KSEA" that any self-development of human beings observed or seen and four side viewing angle namely in the form of integration of knowledge visits and academic abilities, skills visits and trainings attended, work experience based on length of service, and attitude. All of human resources have knowledge supported by the skills of the human resources that are reliable. The skills of human resources supported by a mature work experience are a human resources capability. Human resources, who have experience working with high attitude, will be human resources professional. Fogg (2004: 90) that divides Competence competency into two (2) categories: basic competence and basic competencies that differentiate (Threshold) and distinctive competencies (differentiating) according to criteria that are used to predict the performance of a job. Basic competence (Threshold competencies) are the main characteristics, which is usually in the form of knowledge or basic skills such as the ability to read, while the differentiating competencies are competencies that make a person different from another.

Competence comes from the word competency is a noun which, according to Powell (1997: 142) is defined as 1) the skills, ability, competence 2) authority. The adjective of competence is competent which means competent, capable, and agile. Definition of competence is in principle the same as the notion of competence according to Stephen Robbins (2007: 38) that competence is the ability (ability) or a person's capacity to perform various tasks in a job, in which this ability is determined by two (2) factors which intellectual ability and capability physical. Empirical evidence suggests that competency positive and significant effect on job satisfaction (Anik Suwarni 2008; Hasrul Sardy, 2010; Charles M. Coco, 2011; Hotman, 2011; Hidayat Pontoh, 2012; Soleiman Yahyazadeh et al., 2012; Danang Mukti Wibowo, 2014). The results of these studies differ with the findings of other researchers. In another study it was found that the competence has a significant influence on employee performance (Anik Suwarni, 2008; Hasrul Sardy, 2010; Hotman, 2011; Charles M. Coco, 2011; 
Soleiman Yahyazadeh et al., 2012; Hidayat Pontoh, 2012; Danang Mukti Wibowo 2014; Deddy Pandaleke, 2016).

$\mathrm{H}_{3}$ : Competence positive and significant on job satisfaction

$\mathrm{H}_{4}$ : Competence positive and significant on employee performance

\section{Job satisfaction}

Every individual has a level of job satisfaction varies according to the value system that applies to him. The higher of perceived the job satisfaction in accordance with the desire of individuals, the higher the satisfaction of its work to the activity. Job satisfaction is an evaluation that describes someone for achieving work objectives, work performance, the realization of the target, and welfare (Riva, 2007: 475). Job satisfaction is the work result achieved in executing the tasks assigned to them based on the actualization of the work based on the achievement of work objectives, work performance, the realization of the target, and welfare (Hasibuan, 2001: 105). According to Huggert (2007: 66) successful organizations are always marked by the fulfillment of job satisfaction. Expectations theory states that job satisfaction one is judged based on the fulfillment of goal achievement, accomplishment, realization, targeted and well-being. More fulfilled expectations, the more satisfied of the work produced. No doubt, at this time of job satisfaction becomes important thing to remember in performing work activities, each employee is confronted their job competition, so it required to continuously improve the development of job satisfaction. Job satisfaction according to Whitmore (1999: 72) is a measure of the work achieved by the resources of an organization which is usually expressed in accordance with the desired job satisfaction, job satisfaction and job satisfaction needed to be expected. In other words, the sense of job satisfaction has three dimensions. The first dimension relates to attaining maximum work, in the sense of achieving the targets related to quantity and quality. The second dimension relates to the realization of the input needs completion in obtaining of work activity and employment benefits and the implementation of the duties and functions efficiently, effectively and productively. And the third dimension relates to the hope that the achievement of organizational goals.

Robbins (2006: 101) argues that to measure job satisfaction should be interpreted broadly so that the concept can meet the standards of interaction within an organization's policies and standards to meet the increase in work activities in accordance with the ideal working conditions. This means the assessment of job satisfaction is an important role in doing work activities in accordance with the objectives of the organization. Job satisfaction is usually defined as a positive influence employees' level of job or job situation (Locke, 1976: Spector, 1977). Positive influence on this definition can be added cognitive and behavioral components, it is appropriate to define how social psychological attitudes (Zanna and Rempel, 1988). Job satisfaction is the fact the employee attitudes toward work. Cognitive aspects of employee job satisfaction are a confidence about his work, namely the belief that the job attractive, unattractive, many demands and so on. The cognitive aspect is not free from affective aspect that is strongly associated with feelings of positive influence. Component behavior is more often the employee's behavior or behavioral tendencies toward his work. The level of employee satisfaction also become apparent by the fact that he tried to follow regular job, working hard, and intends to remain a member of the organization for a long time. Compared to the cognitive and affective components of job satisfaction, behavior component slightly informative, because attitude is not always consistent with the behavior, such as someone does not like his job but remain as an employee for reasons Financial.

According to Wexley and Yukl $(1977 ; 151)$ there are three kinds of commonly recognized: (1) Discrepancy Theory, that an employee would be satisfied if there is no difference between what is desired by his perception of reality. (2) Equity Theory. People will feel satisfied or dissatisfied, depending on whether he felt equity or not on a situation. According to this theory equity consists of three elements, namely: (a) Input, that everything worthwhile perceived by employees as a donation for its work. (b) Outcomes, that everything worthwhile perceived by employees as a result of his work. (c). Comparison persons, namely to others or with whom the employee comparing the ratio of input-outcomes. Its Persons Comparison This could be someone in the same company, or elsewhere, or can also by itself in the past. The findings of previous researchers provide evidence that job satisfaction is not significant influence on employee performance (Deddy Pandaleke, 2016). Job satisfaction has a significant effect on employee performance (Diana Sulianti Tobing, 2009; Mohamad Zaid Mustafa et al. 2014; Ida Respatiningsih and Frans Sudirjo, 2015; Ni Komang Sri Wahyudi and I Gede Adnyana Sudibya, 2016).

$\mathrm{H}_{5}$ : Job satisfaction has a positive and significantly effect on employee performance

\section{Employee performance}

According to Furtwengler (2004: 96) that the organization working to realize the organization's performance. Assess organizational performance based on achievement of a series of work activities in terms of quantity, quality, efficiency and effectiveness. The higher a person's work performance, the optimal attainment 
The effect of organizational commitment, competence on Job satisfaction and employees ..

of organizational goals. The results of the work by Norton and Luthans (2005: 69) are a series of activities and actions that generate employment in terms of quantity, quality, efficiency and effectiveness. Sastrohadiwirya (2005: 232) argues that performance appraisal is a subjective and objective process regarding the work that has been achieved and the work that can be assessed using a variety of sizes, principles and rules - rules which can be assessed fairly, integrated and optimalized. Achievement of the objectives set one individual performance benchmarks. There are three criteria in assessing individual performance, namely: (a) the individual tasks; (b) the behavior of individuals and (c) the individual characteristics (Robbins, 2006; 74).

The findings of previous researchers provide evidence that organizational commitment is a positive and insignificant effect on employee performance as a mediated job satisfaction (Diana Sulianti Tobing, 2009; Mohamad Zaid Mustafa et al. 2014). Other evidence, that organizational commitment has a negative and significant effect on employee's performance as a mediated job satisfaction (Soleiman Yahyazadeh et al (2012). In another study it was found that the competency is a positive and not significant effect on employee's performance as a mediated job satisfaction (Mohamad Zaid Mustafa et al. 2014). Other evidence, that competence is a negative and significant effect on employee's performance through job satisfaction (Soleiman Yahyazadeh et al. 2012)

$\mathrm{H}_{6}$ : Organizational commitment has a positive and significantly effect on employee performance as a mediated Job satisfaction

$\mathrm{H}_{7}$ : Competence has a positive and significantly effect on employee performance as a mediated Job satisfaction

\section{Methods}

This study is explanatory Research in that they seek to find relationships that are relatively new, and is done by way of explaining the symptoms caused by an object of study in this case 632 employees working in 14 local government agencies (SKPD) in Maluku Governor's Office as research objects. There are 244 samples. Testing the hypothesis of the study carried out by Partial Least Squares Structural Equation Modeling (PLSSEM) with the WarpPLS 4.0.

\section{Respondents}

\section{Results}

General description of the respondents expressed through the elaboration of gender, age and level of education and Work experience (years).

Table 2. Respondents

\begin{tabular}{|c|c|c|c|}
\hline \multirow{2}{*}{ Respondents } & \multirow{2}{*}{ Characteristics } & \multicolumn{2}{|c|}{ Number of respondents } \\
\cline { 3 - 4 } & & $\mathbf{F}$ & \multicolumn{2}{c|}{$\mathbf{\%}$} \\
\hline \multirow{3}{*}{ Gender } & Male & 131 & 53,6 \\
& Female & 113 & 46,4 \\
\hline \multirow{3}{*}{ Ages } & $21-30$ & 54 & 22.1 \\
& $31-40$ & 93 & 38.1 \\
& $41-50$ & 50 & 20.4 \\
& $>50$ & 47 & 19.2 \\
\hline \multirow{2}{*}{ Educational level } & Doctoral & 17 & 6.9 \\
& Master's Bachelor & 34 & 13.9 \\
& Associate Senior High & 102 & 41.8 \\
& School & 40 & 16.3 \\
& & 51 & 20.9 \\
\hline \multirow{2}{*}{ Work experience } & $1-5$ & 31 & 12.7 \\
& $6-10$ & 42 & 17.2 \\
& $11-15$ & 70 & 28.6 \\
& $>15$ & 101 & 41.3 \\
\hline
\end{tabular}

Generally employees of the gender is male, the number of $131(53 \%)$ with ages between $31-40$ years as many as 93 people (38.1\%). Employee generally educated Bachelor of as many as 102 people (41.8\%). While working period for $>15$ years, or approximately $(41.3 \%)$ according to the age of employees.

\section{Convergent Validity}

Convergent validity is used to test whether the indicators used capable of accurately measuring latent constructs (Garson, 2002). In this study indicators of latent variables that have previously been tested. Testing 
The effect of organizational commitment, competence on Job satisfaction and employees ..

convergent validity on the PLS can be seen from the magnitude of the factor loading of each indicator against latent variables.

Table 3. Convergent validity

\begin{tabular}{|c|c|c|c|c|c|}
\hline Variables & Indicator & Loading & Type(a & $\mathrm{SE}$ & $P$ value \\
\hline \multirow{15}{*}{$\begin{array}{l}\text { Organizational } \\
\text { Commitment } \\
\text { (OC) }\end{array}$} & Happy $\left(\mathrm{X}_{11}\right)$ & 0.485 & Reflect & 0.059 & $<0.001$ \\
\hline & Sensing $\left(\mathrm{X}_{12}\right)$ & 0501 & Reflect & 0.059 & $<0.001$ \\
\hline & Thinking $\left(\mathrm{X}_{13}\right)$ & 0561 & Reflect & 0.058 & $<0.001$ \\
\hline & Tied Emotional $\left(\mathrm{X}_{14}\right)$ & 0523 & Reflect & 0.058 & $<0.001$ \\
\hline & Worry $\left(\mathrm{X}_{15}\right)$ & 0.503 & Reflect & 0.059 & $<0.001$ \\
\hline & a sense of belonging $\left(\mathrm{X}_{16}\right)$ & 0522 & Reflect & 0058 & $<0001$ \\
\hline & Fewer options $\left(\mathrm{X}_{17}\right)$ & 0463 & Reflect & 0.059 & $<0.001$ \\
\hline & Alternative $\left(\mathrm{X}_{18}\right)$ & 0162 & Reflect & 0062 & 0005 \\
\hline & Sacrifice $\left(\mathrm{X}_{19}\right)$ & 0452 & Reflect & 0.059 & $<0.001$ \\
\hline & Loyal $\left(\mathrm{X}_{110}\right)$ & 0551 & Reflect & 0.058 & $<0.001$ \\
\hline & Liabilities $\left(\mathrm{X}_{111}\right)$ & 0462 & Reflect & 0.059 & $<0.001$ \\
\hline & Faithful $\left(\mathrm{X}_{112}\right)$ & 0329 & Reflect & 0.060 & $<0.001$ \\
\hline & Working $\left(\mathrm{X}_{113}\right)$ & 0535 & Reflect & 0.058 & $<0.001$ \\
\hline & One Organization $\left(\mathrm{X}_{114}\right)$ & 0619 & Reflect & 0057 & $<0.001$ \\
\hline & Wise $\left(\mathrm{X}_{115}\right)$ & 0489 & Reflect & 0059 & $<0001$ \\
\hline \multirow{5}{*}{$\begin{array}{l}\text { Competence } \\
\text { (Com) }\end{array}$} & Knowledge $\left(\mathrm{X}_{21}\right)$ & 0756 & Reflect & 0.056 & $<0.001$ \\
\hline & Skill $\left(\mathrm{X}_{22}\right)$ & 0861 & Reflect & 0.055 & $<0.001$ \\
\hline & Mastery $\left(\mathrm{X}_{23}\right)$ & 0855 & Reflect & 0.055 & $<0.001$ \\
\hline & Professionalism $\left(\mathrm{X}_{24}\right)$ & 0.799 & Reflect & 0.056 & $<0.001$ \\
\hline & Experience $\left(\mathrm{X}_{25}\right)$ & 0.738 & Reflect & 0.056 & $<0.001$ \\
\hline \multirow{6}{*}{$\begin{array}{c}\text { Job Satisfaction } \\
\text { (JS) }\end{array}$} & Job $\left(\mathrm{Y}_{11}\right)$ & 0.750 & Reflect & 0.056 & $<0.001$ \\
\hline & Oriented $\left(\mathrm{Y}_{12}\right)$ & 0.533 & Reflect & 0.058 & $<0.001$ \\
\hline & Target $\left(\mathrm{Y}_{13}\right)$ & 0754 & Reflect & 0.056 & $<0.001$ \\
\hline & Settlement $\left(\mathrm{Y}_{14}\right)$ & 0681 & Reflect & 0057 & $<0.001$ \\
\hline & Allowances $\left(\mathrm{Y}_{15}\right)$ & 0719 & Reflect & 0.056 & $<0.001$ \\
\hline & Rewards $\left(\mathrm{Y}_{16}\right)$ & 0743 & Reflect & 0056 & $<0001$ \\
\hline \multirow{6}{*}{$\begin{array}{l}\text { Employee } \\
\text { performance } \\
\text { (Ep) }\end{array}$} & Work Plan $\left(\mathrm{Z}_{11}\right)$ & 0873 & Reflect & 0.055 & $<0.001$ \\
\hline & Standard $\left(\mathrm{Z}_{12}\right)$ & 0.740 & Reflect & 0.056 & $<0.001$ \\
\hline & $\operatorname{Minimize}\left(\mathrm{Z}_{13}\right)$ & 0760 & Reflect & 0.056 & $<0.001$ \\
\hline & Timely $\left(Z_{14}\right)$ & 0728 & Reflect & 0056 & $<0001$ \\
\hline & Work hours $\left(Z_{15}\right)$ & 0.820 & Reflect & 0.056 & $<0.001$ \\
\hline & Settlement $\left(\mathrm{Z}_{16}\right)$ & 0791 & Reflect & 0.056 & $<0.001$ \\
\hline
\end{tabular}

The table explains that each indicator has a latent variable loading $>0.50$, and $p$-Value $<0,001$ yang show that indicators able to good measure latent variables. Thus the measurements for each of the latent variables in this study meet the test criteria of convergent validity, in the sense of meaning constructs capable of measuring latent variables being measured.

\section{Discriminant Validity}

The good measurement is to be unidimensional, which can precisely measure what is measurable (converging) and does not measure other constructs (discriminant). Discriminant validity is used to test whether construct indicators are not correlated with other indicators or at least construct these indicators are lower correlated with indicators of other constructs (Garson, 2002). 
The effect of organizational commitment, competence on Job satisfaction and employees ..

Table 4. Cross loadings

\begin{tabular}{|c|c|c|c|c|c|}
\hline \multicolumn{2}{|c|}{ Measurement } & $(\mathrm{OC})$ & $(\mathrm{Com})$ & $(\mathrm{JS})$ & $(\mathrm{Ep})$ \\
\hline \multirow{15}{*}{ Organizational Commitment (OC) } & Happy $\left(\mathrm{X}_{11}\right)$ & 0.567 & 0.234 & 0.831 & -0.363 \\
\hline & Sensing $\left(\mathrm{X}_{12}\right)$ & 0.753 & 0.503 & -0.098 & 0.500 \\
\hline & Thinking $\left(\mathrm{X}_{13}\right)$ & 0.807 & 0.560 & 0.112 & 0.336 \\
\hline & Tied Emotional $\left(\mathrm{X}_{14}\right)$ & 0.819 & 0.590 & -0.153 & 0.534 \\
\hline & Worry $\left(\mathrm{X}_{15}\right)$ & 0.703 & 0.518 & -0.417 & 0.544 \\
\hline & a sense of belonging $\left(\mathrm{X}_{16}\right)$ & 0.764 & 0.539 & -0.183 & 0.495 \\
\hline & Fewer options $\left(\mathrm{X}_{17}\right)$ & 0.521 & 0.479 & 0.019 & 0.781 \\
\hline & Alternative $\left(\mathrm{X}_{18}\right)$ & 0.805 & 0.689 & -0.555 & -0.185 \\
\hline & Sacrifice $\left(\mathrm{X}_{19}\right)$ & 0.963 & -0.494 & 0.019 & -0.190 \\
\hline & Loyal $\left(\mathrm{X}_{110}\right)$ & 0.991 & -0.351 & 0.093 & -0.296 \\
\hline & Liabilities $\left(\mathrm{X}_{111}\right)$ & 0.992 & -0.421 & -0.042 & -0.183 \\
\hline & Faithful $\left(\mathrm{X}_{112}\right)$ & 0.892 & -0.382 & -0.301 & 0.341 \\
\hline & Working $\left(\mathrm{X}_{113}\right)$ & 0.985 & -0.268 & -0.057 & -0.253 \\
\hline & One Organization $\left(\mathrm{X}_{114}\right)$ & 0.996 & -0.399 & 0.013 & -0.199 \\
\hline & Wise $\left(\mathrm{X}_{115}\right)$ & 0.988 & -0.314 & 0.100 & -0.382 \\
\hline \multirow{5}{*}{ Competence (Com) } & Knowledge $\left(\mathrm{X}_{21}\right)$ & 0.057 & 0.640 & -0.179 & 0.395 \\
\hline & Skill $\left(\mathrm{X}_{22}\right)$ & 0.015 & 0.653 & 0.116 & -0.123 \\
\hline & Mastery $\left(\mathrm{X}_{23}\right)$ & -0.012 & 0.680 & 0.085 & -0.233 \\
\hline & Professionalism $\left(\mathrm{X}_{24}\right)$ & -0.019 & 0.667 & -0.034 & 0.035 \\
\hline & Experience $\left(\mathrm{X}_{25}\right)$ & -0.036 & 0.677 & -0.099 & 0.145 \\
\hline \multirow{6}{*}{ Job Satisfaction (JS) } & $\operatorname{Job}\left(\mathrm{Y}_{11}\right)$ & 0.026 & -0.035 & 0.647 & 0.340 \\
\hline & Oriented $\left(\mathrm{Y}_{12}\right)$ & 0.108 & -0.226 & 0.711 & -0.091 \\
\hline & Target $\left(\mathrm{Y}_{13}\right)$ & -0.014 & 0.141 & 0.716 & -0.368 \\
\hline & Settlement $\left(\mathrm{Y}_{14}\right)$ & 0.104 & -0.163 & 0.732 & -0.250 \\
\hline & Allowances $\left(\mathrm{Y}_{15}\right)$ & -0.112 & 0.040 & 0.636 & 0.498 \\
\hline & Rewards $\left(\mathrm{Y}_{16}\right)$ & -0.144 & 0.187 & 0.651 & 0.273 \\
\hline \multirow{6}{*}{ Employee performance (Ep) } & Work Plan $\left(\mathrm{Z}_{11}\right)$ & 0.052 & 0.186 & -0.099 & 0.651 \\
\hline & Standard $\left(\mathrm{Z}_{12}\right)$ & 0.001 & 0.167 & -0.075 & 0.656 \\
\hline & $\operatorname{Minimize}\left(\mathrm{Z}_{13}\right)$ & -0.029 & -0.228 & 0.067 & 0.695 \\
\hline & Timely $\left(Z_{14}\right)$ & 0.089 & -0.036 & 0.285 & 0.638 \\
\hline & Work hours $\left(Z_{15}\right)$ & -0.087 & 0.121 & -0.000 & 0.668 \\
\hline & Settlement $\left(\mathrm{Z}_{16}\right)$ & -0.002 & -0.157 & -0.078 & 0.702 \\
\hline
\end{tabular}

The value of the Factor Loading on the latent variables was higher than cross loading. This indicates that the latent constructs have been predicting its own indicator is better than the other predicting latent indicator so it can meet the criteria of interpretation that have discriminant validity. In addition, testing discriminant validity than through comparison of loading with cross loading needs to be strengthened by examining AVE and comparison square root of the average variance extracted (AVE) with the correlation between the latent variables. AVE demonstrated ability in representing the value of the latent variable scores the original data (before extraction). AVE is identical to the multiple $\mathrm{R}^{2}$ (coefficient of determination), so the larger the AVE, the greater the value of the original variable by a score factor. Cut-off value AVE is $\geq 0.50$. The value average variance extracted (AVE) and the correlation between the latent variables are presented in the following table.

Table 5. Average variance extracted (AVE)

\begin{tabular}{|l|c|c|c|c|c|c|}
\hline \multicolumn{1}{|c|}{ variable } & \multirow{2}{*}{ AVE } & \multirow{2}{*}{ Corre } & \multicolumn{4}{c|}{ Correlation matrix } \\
\cline { 4 - 8 } & & & $(\mathrm{OC})$ & $(\mathrm{Com})$ & $(\mathrm{JS})$ & $(\mathrm{Ep})$ \\
\hline Organizational Commitment (OC) & 0,339 & 0,582 & 0.582 & 0.529 & 0.460 & 0.445 \\
\hline Competence (Com) & 0,645 & 0,803 & 0.529 & 0.803 & 0.674 & 0.731 \\
\hline Job Satisfaction (JS) & 0,492 & 0,701 & 0.460 & 0.674 & 0.701 & 0.712 \\
\hline Employee performance (Ep) & 0,619 & 0,787 & 0.445 & 0.731 & 0.712 & 0.787 \\
\hline
\end{tabular}

The table explains that organizational commitment most strongly correlated with organizational commitment, organizational commitment is correlated most strongly with performance. Job satisfaction correlated most strongly with the performance. Value correlations among these variables, are all lower than the value of $\sqrt{A V E}$ latent variables, so it is concluded that the measurement of all four latent variables have discriminant validity is good, that can be distinguished from measurement variables latent other. 
The effect of organizational commitment, competence on Job satisfaction and employees ..

\section{Reliability}

Reliability reflects the consistency of the results of measurements carried out repeatedly on the same subject. If the results are consistent, then the measuring instrument is considered reliable or trustworthy

Table 6. Composite Reliability

\begin{tabular}{|l|c|c|}
\hline \multicolumn{1}{|c|}{ Variable } & Composite Reliability & Cronbach's alpha \\
\hline Organizational Commitment (OC) & 0.818 & 0.761 \\
\hline Competence (Com) & 0.901 & 0.861 \\
\hline Job Satisfaction (JS) & 0.851 & 0.789 \\
\hline Employee performance (Ep) & 0.907 & 0.876 \\
\hline
\end{tabular}

The level of reliability of the measurement of the variables is good, because each variable composite reliabllity of $>0.70$.

\section{Inner models}

Testing of inner models include two stages, namely: (1) to test the goodness of fit and (2) to test the significance of the path. Testing of path coefficients in structural model means also test the hypothesis proposed in this study because the hypothesis formulated reflected in path ways that exist in the model.

Figure 1. Results of Inner Model (Original Sample Estimate)

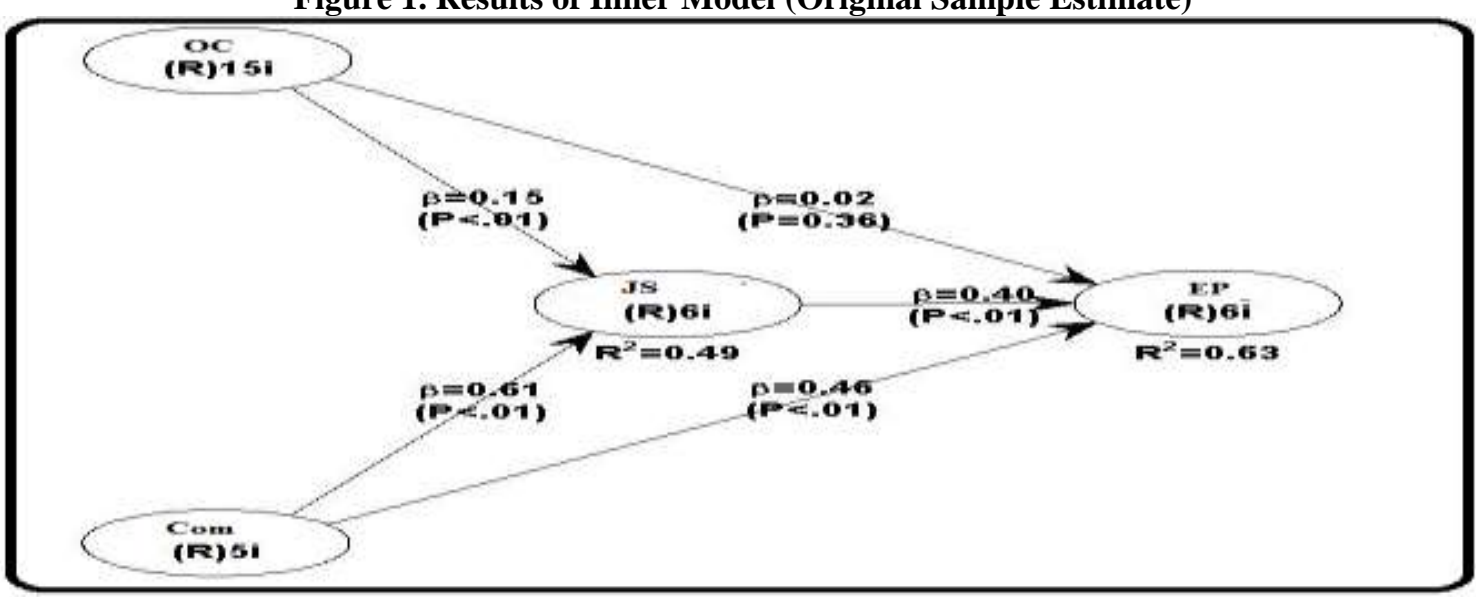

6. Goodness of fit

Test is intended to determine how much the result of a data model that explains variations (score) the original variable. Tests conducted by Stone-Geisser Q Square test. From the structural models is known that there are two dependent variables, namely job satisfaction and performance, in order to obtain two coefficients of determination. PLS output values obtained from the coefficient of determination for each dependent variable as presented in the following table.

Table 7. R-square

\begin{tabular}{|c|l|l|c|}
\hline Equations & \multicolumn{1}{|c|}{ Independent } & \multicolumn{1}{|c|}{ Dependent } & R-square \\
\hline 1 & $(\mathrm{OC})$ and $(\mathrm{Com})$ & job satisfaction & 0,488 \\
\hline 2 & $(\mathrm{OC}),(\mathrm{Com})$ and $(\mathrm{JS})$ & Performance & 0.627 \\
\hline
\end{tabular}

Based on the coefficient of determination of each dependent variable $\mathrm{Q}^{2}$ sought by the formula:

$\mathrm{Q}^{2}=1-\left(1-\mathrm{R}_{1}{ }^{2}\right)\left(1-\mathrm{R}_{2}{ }^{2}\right)$

Description:

$\mathrm{R} 1^{2}=$ coefficient of determination for the endogenous variables job satisfaction,

$\mathrm{R} 2^{2}=$ coefficient of determination for performance endogenous variables,

$\mathrm{Q}^{2}=\{1-(1-0,488)(1-0.627)\}$

$\mathrm{Q}^{2}=\{1-0.191\}=0.809$

Based on the coefficient of determination of the three dependent variables in the model, it can be seen Stone-Geisser Q Square is 0.809 . These results indicate that the model has a good feasibility, because the model is able to describe the actual conditions which amounted to $80.9 \%$, while the remaining $19.1 \%$ is a limitation of the research instruments 
The effect of organizational commitment, competence on Job satisfaction and employees ..

Table 8. Evaluation of models

\begin{tabular}{|l|c|c|}
\hline \multicolumn{1}{|c|}{ Goodness of fit } & Quality Indices & Model *Results \\
\hline APC & - & $0.329, \mathrm{P}<0.001$ \\
\hline ARS & - & $0.562, \mathrm{P}<0.001$ \\
\hline AARS & - & $0.557, \mathrm{P}<0.001$ \\
\hline AVIF & \multicolumn{1}{|c|}{$-1,592$} \\
\hline AFVIF & acceptable if $<=5$, ideally $<=3,3$ & 2,246 \\
\hline GoF & acceptable if $<=5$, ideally $<=3,3$ & 0,529 \\
\hline SPR & small $>=0.1$, medium $>=0.25$, large $>=0.36$ & 1,000 \\
\hline RSCR & acceptable if $>=0.7$, ideally $=1$ & 1,000 \\
\hline SSR & acceptable if $>=0.9$, ideally $=1$ & 1,000 \\
\hline NLBCDR & acceptable if $>=0.7$ & 1,000 \\
\hline
\end{tabular}

7. Hypothesis

Testing the hypothesis by looking at the p-value, if the p-value $<0.05$ then the relationship between significant variables. It also describes the direct effect means that there are positive influence directly between variables, the indirect effect means that there are positive influence indirectly between variables, and the total effect is the accumulation of direct and indirectly effect.

Table 9. Hypothesis Testing

\begin{tabular}{|c|c|c|c|c|c|}
\hline \multirow{2}{*}{ Hypothesis } & \multirow{2}{*}{ Independent } & \multirow[t]{2}{*}{ Dependent } & \multicolumn{3}{|c|}{ Direct Effect } \\
\hline & & & coefficient & SE & p-value \\
\hline $\mathrm{H}_{1}$ & $(\mathrm{OC})$ & $(\mathrm{JS})$ & 0,154 & 0,062 & 0,007 \\
\hline $\mathrm{H}_{2}$ & (Com) & (JS) & 0.661 & 0.058 & $<0.001$ \\
\hline $\mathrm{H}_{3}$ & $(\mathrm{OC})$ & (Ep) & 0,024 & 0,064 & 0.356 \\
\hline $\mathrm{H}_{4}$ & $(\mathrm{Com})$ & (Ep) & 0.461 & 0.059 & $<0.001$ \\
\hline \multirow[t]{3}{*}{$\mathrm{H}_{5}$} & (JS) & (Ep) & 0.395 & 0.060 & $<0.001$ \\
\hline & \multirow{2}{*}{ Independent } & \multirow{2}{*}{ Dependent } & \multirow{2}{*}{ Intervening } & \multicolumn{2}{|c|}{ Indirect Effect } \\
\hline & & & & coefficient & p-value \\
\hline $\mathrm{H}_{6}$ & $(\mathrm{OC})$ & (Ep) & (JS) & 0.061 & 0.088 \\
\hline $\mathrm{H}_{7}$ & (Com) & (Ep) & (JS) & 0.241 & $<0.001$ \\
\hline \multirow{2}{*}{\multicolumn{2}{|c|}{ Independent }} & \multirow{2}{*}{\multicolumn{2}{|c|}{ Dependent }} & \multicolumn{2}{|c|}{ Total Effect } \\
\hline & & & & coefficient & p-value \\
\hline & $(\mathrm{OC})$ & & & 0,154 & 0,007 \\
\hline & $(\mathrm{Com})$ & & & 0.661 & $<0.001$ \\
\hline & $(\mathrm{OC})$ & & & 0.084 & 0.091 \\
\hline & (Com) & & & 0.703 & $<0.001$ \\
\hline & $(\mathrm{JS})$ & & & 0.395 & $<0.001$ \\
\hline
\end{tabular}

7.1. Organizational commitment is positive and significantly effect on job satisfaction with p-value $0.007<0.05$ and the coefficient value of 0.154 . This means that the better the organization owned the commitment will further increase job satisfaction. Organizational commitment of employees is very important for organizations and individuals in carrying out activities or tasks a person as they will do the job in an effort to realize them according to the degree of job satisfaction of their work each. Organizational commitment play an important role for every individual as an employee in carrying out the duties and responsibilities as an in doing the job. Through the organizational commitment in the form of happy, feel, think, bound to emotional, worried, sense of belonging, little choice, alternative, sacrifice, loyalty, obligation, loyal, working, one organization, thoughtful, giving the sense of a meaningful and significant effect on job satisfaction of employees at the Maluku Governor's Office. The implementation of the organizational commitment to be important and necessary as the embodiment of the totality of employee loyalty to behave to promote and realize the goals of the organization. Fidelity organizational commitment is defined as the totality of each employee's work activities well in order to improve employee satisfaction. This study supports previous research findings that organizational commitment and significant positive effect on job satisfaction (Hotman, 2011; Charles M. Coco, 2011; Hidayat Pontoh, 2012; Soleiman Yahyazadeh et al., 2012). Rejecting the findings of other researchers, that organizational commitment is a negative and significant effect on job satisfaction (Anik Suwarni, 2008). Organizational commitment is negative and insignificant effect on job satisfaction (Danang Mukti Wibowo, 2014).

7.2. Competence is a positive and significant effect on job satisfaction with p-value $0.000<0.05$ and the coefficient value of 0.661 . This means that the better the competency of employees increase job satisfaction. Employee competency is essential for organizations and individuals in carrying out activities or tasks a person as they will do the job in an effort to realize them according to the degree of job satisfaction of their work each. Competence is important for the individual as an employee in carrying out the duties and responsibilities as an in doing the job. Through knowledge, skill, mastery, professionalism and experience provide a meaningful and tangible sense on job satisfaction of employees at the Maluku Governor's Office. These studies refute the findings of previous investigators, that competence not 
significant effect on job satisfaction (Mohammad Zaid Mustafa et al. 2014; Muhamad Arifin, 2015; Deddy Pandaleke, 2016). Supports the findings of other researchers that Competency positive and significant impact on job satisfaction (Anik Suwarni 2008; Hasrul Sardy, 2010; Charles M. Coco, 2011; Hotman, 2011; Hidayat Pontoh, 2012; Soleiman Yahyazadeh et al., 2012; Danang Mukti Wibowo, 2014).

7.3. Organizational commitment is a positive and insignificant effect on employee performance of the p-value $0.356>0.05$ and the coefficient value of 0.024 . This means that either owned organizational commitment does not improve performance. The employees expected to always obey the rules of the organization as normative, expected employee is able to commit to realize the goal of continuous organization and every employee is expected to make organizations sustain success into perspective. Commitment owned by Maluku Governor's Office employee has been actualized with good, but not significant to the achievement of employee performance. Commitment owned by employees are not oriented to the achievement of the work, visible between employee commitment that has not encouraging employees to achieve work in quantity, by being able to settle the amount of work that a lot was given to him, a commitment which is owned not oriented to improving the quality of work in accordance with dedication work has, employee commitment does not lead to the completion of the work on time and employees' commitment not notice or consider the utilization and use of fees to expedite completion of the work. Supports the findings of previous investigators, that organizational commitment insignificant effect on employee performance (Danang Mukti Wibowo, 2014; Deddy Pandaleke, 2016). The findings of this study differs from other research that organizational commitment is a negative and significant effect on employee performance (Anik Suwarni, 2008). Organizational commitment is a positive and significant effect on employee performance (Diana Sulianti Tobing, 2009; Hotman, 2011; Charles M. Coco, 2011; Hidayat Pontoh, 2012; Soleiman Yahyazadeh et al., 2012; Ida Respatiningsih and Frans Sudirjo, 2015; Ni komang Sri Wahyudi and Gede Adnyana Sudibya, 2016).

7.4. Employee competence is a positive and significant effect on employee performance. The p-value of $0.000<$ 0.05 and the coefficient value of 0.461 . This means that the higher the employees competence more real result on improving the performance of employees. Competence and performance of employees is fundamental to every employee in showing the potential for him to obtain optimal results. For employees, competence becomes fundamental for its ability to carry out a given job. The whole ability of employees who harnessed and used to perform basic tasks and functions appropriate knowledge, skills, experience, attitude and professional work. Employees who have the competence always show thinking smart, work reliable, experienced, skilled and professional in generating optimal job, in terms of the amount of work in terms of quantity produced, the value of quality work, efficient use of time and on the use of the effective budget on organization. The results of this study support the findings of other researchers. In other studies, that competence significantly influence on employee performance (Anik Suwarni, 2008; Hasrul Sardy, 2010; Hotman, 2011; Charles M. Coco, 2011; Soleiman Yahyazadeh et al., 2012; Hidayat Pontoh, 2012; Danang Mukti Wibowo, 2014 ; Deddy Pandaleke, 2016)

7.5. Job satisfaction is a positive and significant effect on employee performance. The p-value of $0.000<0.05$ and the coefficient value of 0.395 . This means that the better job satisfaction owned then further improves the performance of employees. Perceived job satisfaction of employees in the form of job-oriented, targeted, completion, benefits and rewards positive and significant impact on the performance. This means that through job satisfaction indicators are owned by employees give real meaning to employee performance in the Maluku Governor's Office. Increased job satisfaction of employees, it is important to be noticed and considered in order to achieve organizational sustainability. Job satisfaction is a feeling pleasant disclosure or disappointing for the achievement of the work effort that has been done. Employee discloses a satisfied feeling characterized by a pleasant expression or shows a serious action and innovative work, and disgruntled employees usually express disappointment or indicates action is lazy and eager to work. The impact of employee job satisfaction owned directly influence a positive and significant impact on employee performance improvement in terms of quantity, quality, efficient and effective shown in performing routine activities within an organization. This study rejects findings of previous investigators, that job satisfaction is not significant influence on employee performance (Deddy Pandaleke, 2016). Then give support to other researchers, that job satisfaction have a significant effect on employee performance (Diana Sulianti Tobing, 2009; Mohamad Zaid Mustafa et al. 2014; Ida Respatiningsih and Frans sudirjo, 2015; Ni komang Sri Wahyudi and I Gede Adnyana Sudibya, 2016)

7.6. Organizational commitment is positive and not significant effect on employee performance as a mediated job satisfaction. The p-value of $0.088>0.05$ and the coefficient value of 0.061 . This means that the commitment of both organizations is able to create job satisfaction but has not been able to improve the employee's performance. Organizational commitment in an organization has always had a major role through job satisfaction on employee performance. Organizational commitment is defined as an effort to improve compliance of an employee to perform the duties and functions within an organization. Consider 
the presence of an employee-owned organization's commitment to be a very urgent for consideration through job satisfaction on employee performance. The reason of organizational commitment has a positive and insignificant effect on employee performance as a mediated job satisfaction because the commitment which is owned not oriented to the achievement of the work, visible between employee commitment that has not encouraging employees to achieve work in quantity, by being able to settle the amount of work that many authority, commitment owned not oriented to improving the quality of work in accordance with its dedication to work, commitment does not lead to the timely completion of the work, minimize errors and timeliness of work. Commitments are not oriented to the fulfillment of job satisfaction to employee performance in the Maluku Governor's Office in carrying out the duties and functions of provincial government organizations. This study supports the findings of previous investigators, that organizational commitment is a positive and no significant effect on employee performance as a mediated job satisfaction (Diana Sulianti Tobing, 2009; Mohamad Zaid Mustafa et al. 2014). This study differs from other research that organizational commitment is negative and significant effect on employee's performance as a mediated job satisfaction (Soleiman Yahyazadeh et al., 2012).

7.7. Competence is a positive and significant effect on employee performance as a mediated job satisfaction. The p-value $0.000<0.05$ and the coefficient value of 0.241 . This means that the higher the competency of employee job satisfaction will increase and eventually have an impact on increasing performance. Every employee is required to know and be able to develop good work activities in accordance with their knowledge. In any work activities required the ability of employees who have sufficient working knowledge, so that employees in carrying out its activities able to realize the job satisfaction and job pleased implement the service itself. Employee must be skilled and competent in performing service activities, according to the skill areas of work you have, the skills of employees is very helpful and makes it easy to speed up service activity in accordance with the level of skills possessed, so that employees in carrying out its activities able to realize the job satisfaction and happy carry out the work and employees can improve performance. The results of this study support the findings of previous investigators, that competence is a positive and not significant effect on employee performance as a mediated job satisfaction (Mohamad Zaid Mustafa et al. 2014). Other evidence, that competence a negative and significant effect on employee's performance as a mediated job satisfaction (Soleiman Yahyazadeh et al. 2012).

\section{Conclusion}

Organizational commitment provide positive reinforcement on a happy, feel, think, bound to emotional, worried, sense of belonging, little choice, alternative, sacrifice, loyalty, obligation, loyal, working, one organization, thoughtful, and contributed very strongly on job satisfaction. Employee's competency in the form of knowledge, skill, attitude control, professionalism and experience is a positive and significant impact on job satisfaction. This means that through competency of employees give real meaning to employee satisfaction. Demonstrated organizational commitment of employees in the form of happy, feel, think, emotionally bound, worry, sense of belonging, little choice, alternative, sacrifice, loyalty, obligation, loyal, working, one organization, wisely, does not give a real meaning to employee performance. Competency of employees in the form of knowledge, skill, attitude control, professionalism and experience give real meaning to employee performance. Perceived job satisfaction of employees on the job, oriented, targeted, completion, benefits and rewards give real meaning to employee performance. Organizational commitment as a mediated Job satisfaction is not capable of supporting the creation of employee performance, state different from the competence of the employees that job satisfaction felt by employees proved to be a mediating role in analyzing the effect of competence on employee performance

Implementation of organizational commitment should be the totality of employees in the work so rewarding in any work activities which employees live. A leader of local government agency (SKPD) is required to continue to pay attention and develop their competence as a potential employee, so that every employee showed its satisfaction with the implementation of the Duty and function. Employee competency needs to be maintained and improved so that the potential for a reliable and professional work that does not directly provide job satisfaction for employees to keep improving their performance.

\section{References}

[1] Abdurrahmat Fathoni, (2006), Human Resource Management, Bandung: Rineka Cipta

[2] Ambar, Teguh, Sulistiyani, and Rosidah, (2009), Human Resources Manajamen, Yogyakarta: Graha Ilmu

[3] Anik Suwarni, (2008). Effect of competencies, organizational commitment, discipline on performance and employee satisfaction high school in Java Barat.Journal ofHuman Resources, Vol. 9. 22-29. http // google.com

[4] Charles M. Coco, (2011). Discipline, Motivation, commitmen and Competence in Increasing of Satisfaction and Performance by an Employee in Cambridge Australia.International Journal of Business and Management, Vol.5, No. 6; June 2011

[5] Danang M. Wibowo, (2014). Effect of Competence, motivation, organizational commitment to employee performance and job satisfaction of education. International Journal of Business and Management, Vol.5, No. 6, June 2014

[6] David, French, (2009). Human Resources Management, $2^{\text {nd }}$ Edition, Mas Hougton Miffin Company, Boston 
The effect of organizational commitment, competence on Job satisfaction and employees ..

[7] David, Mc. Clelland. (1997). Human Resource Management. Prenhallindo. Jakarta.

[8] Dedek Kusnadi, (2004). Influence of Human Resource Development and commitment to the performance of staff at the Department of Education and Culture in the province of Jambi, Mahardika Media Journal Vol 13 \# 1 September 2014

[9] Diana Sulianti Tobing, (2009). Influence of Organizational Commitment and Job Satisfaction on Employee Performance PT. Perkebunan Nusantara III in North Sumatra. Journal of Management and Entrepreneurship, Vol.11 No.1 Marc

[10] Dwi Prasetyo (2011). The influence of the motivation, competence and organizational commitment to employee performance PT. BNI Life Insurance, Tbk in Surabaya. Thesis Department of Veterans Univ management eastern Java Development

[11] Fillet. R.Wayne. (2003). Human Resource Management. Allyn \& Bacon

[12] Futwengler, Dale, 2007. Prestation. Published by Harper T \& Row, New York

[13] Hasibuan. SP, Malayu, (2005). HR Organizational Design Concepts. Publisher Mandar Maju

[14] Hotman, (2011). Competence and organizational commitment to job satisfaction to increase employee performance. Journal of Human Resource, Vol.9, 22-29. http // google.com

[15] Ida Respatiningsih and Frans Sudirjo (2015). The influence of organizational commitment, motivation, capabilities, and job satisfaction to employee performance (studies empirilk the district inspectorate pemalang. UNTAG Semarang Scientific Journal ISSN: 2302-2752, Vol 4 No.3

[16] Julian Yoseph, (2012). Competence, commitment and organization discipline to increase employee performance and job satisfaction. Journal of Human Resource, Vol.5, 1-10 http // google.com

[17] Luthans, Fred, (2007). Organizational behavior, New York, McGraw-Hill Book Company, $3^{\text {rd, }}$ edt

[18] Mathis, RL, and JH Jackson, (2001), Human Resource Management, book one and book two, Translation, Salemba Four, Jakarta.

[19] Meyer, JP, and Allen, NJ (1997), Commitment in the workplace theory, research and application. California: Sage Publications.

[20] Mohamad Zaid Mustafa, (2014). Analysis of Motivation, Discipline, Competence and commitmen toward Performance through Satisfaction by Worker Training Council in Abu Dhabi. International Review of Management and HRM Vol. 4, No. 2.2014 ISSN: 2146-4405. www.econjournals.com

[21] Mohmmad Shahoseini, (2012). Affect of Commitment, Competence and Discipline toward Prestation and Performance by Educator on Boston University. Journal of Human Resources, Vol.5. 1-10 http://google.com

[22] Moore, (2011). Competence and Emotional Quotient toward Satisfaction and Performance by an Employee in Malaysia. Research Journal of Recent Sciences. Vol.1 (7), 59-67, July (2011) ISSN: 2277-25021

[23] Muhhamad Arifin. (2015). The Influence of Competence, Motivation, and Organizational Culture to High School Teacher Job Satisfaction and Performance. International Education Studies; Vol. 8, No. 1; 2015 ISSN 1913-9020 E-ISSN 1913-9039 .Published by Canadian Center of Science and Education

[24] Ni Komang Sri Wahyudi I Gede Adnyana Sudibya. (2016). Effect of Job Satisfaction and Organizational Commitment On Employee Performance At Natya Hotel, Kuta Bali. E-Journal of Management Udayana University. Vol.5 no.2 870-897 2016 ISSN: 2302-8912

[25] Robbins, Stephen, P. (2007). Organizational Behavior. Clifs Prentice Hall, New Jersey

[26] Soleiman Yahyazadeh, (2012). Satisfaction and Performance: Path Analysis for tested of Competence, commitmen and Discipline from Employee in New Delhi India. Resecarch Journal of Recent Sciences. Vol.1 (7), July 59-67 (2012) ISSN 2277-2502

Bernard C. Renyut The effect of organizational commitment, competence on Job satisfaction and employees performance in Maluku Governor's Office.” IOSR Journal of Business and Management (IOSR-JBM), vol. 19, no. 11, 2017, pp. 18-29. 